\title{
Aragonite-calcite-dolomite relationships in UHPM polycrystalline carbonate inclusions from the Kokchetav Massif, northern Kazakhstan
}

\author{
ANDREY V. KORSAKOV ${ }^{1, *}$, KRIS DE GUSSEM ${ }^{2}$, VlADIMIR P. ZHUKOV $^{3}$, MARIA PERRAKI $^{4}$, PETER VANDENABEELE 5 \\ and ALEKSANDER V. GOLOVIN ${ }^{1}$ \\ ${ }^{1}$ Institute of Geology and Mineralogy of Siberian Branch Russian Academy of Sciences, Koptyug Pr. 3, \\ Novosibirsk 630090, Russia \\ *Corresponding author, e-mail: korsakov@uiggm.nsc.ru; korsakov@igm.nsc.ru \\ ${ }^{2}$ Department of Analytical Chemistry Raman Research Group, Ghent University, Proeftuinstraat 86, \\ 9000 Ghent, Belgium \\ ${ }^{3}$ Institute of Computational Technologies Siberian Branch of the Russian Academy of Sciences, \\ Acad. Lavrentjev avenue 6, 630090 Novosibirsk, Russia \\ ${ }^{4}$ School of Mining and Metallurgical Engineering, National Technical University of Athens, 9 Heroon Politechniou St., \\ Zografou, Athens, 15773, Greece \\ ${ }^{5}$ Department of Archaeology and Ancient History of Europe, Ghent University, Blandijnberg 2, 9000 Ghent, Belgium
}

\begin{abstract}
The presence of aragonite in polycrystalline carbonate inclusions in garnet in diamond-grade metamorphic rocks from the Kokchetav Massif, N. Kazakhstan was identified for the first time by means of Raman analyses and mapping, cathodoluminescence images and optical and scanning electron microscopy. Aragonite appears within the inclusions as dirty, chaotically oriented materials surrounded by a clean monocrystalline calcite shell; the grain boundary between the host-garnet and the aragonite-bearing inclusions is often characterized by a wavy or amoeboid shape; no cracks occur around the aragonite-bearing inclusions; no significant shift in the main aragonite Raman band was measured. These observations indicate that residual pressure within the inclusion is minor. These features are inconsistent with an origin of aragonite at peak metamorphic conditions (6 GPa) by decomposition of dolomite.
\end{abstract}

Key-words: aragonite, calcite, diamond, UHPM petrology, Raman spectroscopy, SEM, cathodoluminescence.

\section{Introduction}

The upper limit of peak metamorphic conditions (especially the maximum pressure $P_{\max }$ ) has been increased constantly since ultrahigh pressure metamorphism (UHPM) was first defined (Chopin, 1984; Smith, 1984; Sobolev \& Shatsky, 1990). To date the $P_{\max }$ for subducted continental crusts has been estimated at approximately 8-9 GPa (Dobrzhinetskaya et al., 2006; Massonne, 2003; Zhu \& Ogasawara, 2002). Most difficulties in the reconstruction of $P_{\max }$ conditions for metapelites and metacarbonates are mainly related to the lack of reliable geobarometers in the 2.0-8.0 GPa interval (Hermann, 2002, 2003b; Hermann \& Green, 2001; Lappin \& Smith, 1981), although significant progress has been made lately (Thomsen \& Schmidt, 2008, and references therein). Inclusions in robust minerals that point to $\mathrm{UH} P \mathrm{M}$ comprise diamond $(\mathrm{C})$, coesite $\left(\mathrm{SiO}_{2}\right), \mathrm{TiO}_{2}$ polymorph with $\alpha-\mathrm{PbO}_{2}$ structure. Because of the generally very small size of the UHPM inclusions, which are close to the optical limit, analytical techniques for the accurate investigation of these inclusions are largely confined to transmission electron microscopy (TEM) (Dobrzhinetskaya et al., 2006; Hwang et al., 2001, 2004, 2005; Langenhorst, 2003) and Raman spectroscopic point analysis and mapping (Korsakov et al., 2007; O'Brien \& Ziemann, 2008; Ogasawara et al., 2002; Perraki et al., 2006, 2007).

TEM techniques enabled the identification of inclusions of $\mathrm{TiO}_{2}$ polymorphs with $\alpha-\mathrm{PbO}_{2}$ structure in garnet from the UHP Erzgebirge, Germany (Hwang et al., 2001), pointing to a maximum pressure above 4-6 GPa. In addition, inclusions of aragonite and magnesite in diamonds from the UHP Kokchetav Massif, Northern Kazakhstan, identified by TEM with focused ion beam, indicate even higher pressures of approximately 6-9 GPa (Dobrzhinetskaya et al., 2006), on the basis of earlier experimental studies (Buob et al., 2006; Goldsmith \& Newton, 1969; Hermann, 2003a; Irving \& Wyllie, 1975; Luth, 2001; Sato \& Katsura, 2001).

Inclusions of aragonite and pseudomorphs after magnesite were first published by Zhu \& Ogasawara (2002). However, this observation was disputed by Hermann (2003a) who claimed that it is inconsistent with other 
petrological data (for discussion see Hermann et al., 2001; Katayama et al., 2001; Korsakov \& Hermann, 2006; Korsakov et al., 2002, 2004, 2006; Shatsky et al., 1995).

Aragonite inclusions in diamond have recently been interpreted as evidence of very deep subductions of roughly $280 \mathrm{~km}$ (Dobrzhinetskaya et al., 2006) although $P-T$ conditions for the main eclogite stage in the eclogites from the relevant Jæren nappe in the Norwegian Caledonian orogenic belt, have been estimated at 2.3-2.8 $\mathrm{GPa}$ and $585-655^{\circ} \mathrm{C}$ (Smit et al., 2008). Aragonite and magnesite present clear disequilibrium textures, indicating the replacement of magnesite by aragonite (Smit et al., 2008). They are inferred to have occurred via a coupled dissolution/precipitation reaction not related to the breakdown of dolomite.

Inclusions of single dolomite crystals in garnets from UHP metamorphic rocks from the Kokchetav Massif, N. Kazakhstan frequently contain diamonds (Korsakov et al., 2005; Ogasawara et al., 2000; Perraki et al., 2009), although they bear no indicator of the existence of aragonite and magnesite. This observation implies that dolomite was stable over the entire pressure-temperature-time path of the diamond-bearing rocks of Kokchetav (Hermann, 2003a).

Information on aragonite coexisting in equilibrium with magnesite as inclusion in garnet or clinopyroxene is lacking. Dolomite inclusions in garnet from diamond-bearing marbles from the Kokchetav Massif contain multiphase inclusions. They are composed of calcite, magnesite, and amorphous $\mathrm{SiO}_{2}$ with high $\mathrm{H}_{2} \mathrm{O}$ content (Shatsky et al., 2006). The origin of this type of inclusions is related to the crystallization of silicate-carbonate melts (Korsakov \& Hermann, 2006; Korsakov et al., 2006; Shatsky et al., 2006). So far, diamonds were not recognized inside or in association with aragonite or magnesite, although polycrystalline calcite inclusions in garnet and clinopyroxene may contain diamond or graphite inclusions (Korsakov \& Hermann, 2006). Sometimes, polycrystalline calcite inclusions bear cavities or holes indicating that some $\mathrm{H}_{2} \mathrm{O}$ soluble components of carbonate inclusions could have been lost during sample preparation. The lack of a systematic study of the carbonate inclusions by Raman spectroscopy makes it a high possibility that aragonite or other exotic minerals (e.g., $\mathrm{H}_{2} \mathrm{O}$-soluble alkaline carbonates, sulphates) were overlooked ( $c f$. Chopin et al., 2008).

We investigated several polycrystalline carbonate inclusions of the diamond-grade metamorphic rocks from the Kokchetav Massif. The unexposed carbonate inclusions at the thin-section surface were first studied by Raman mapping (RM). The samples were then polished until the inclusions were exposed at the thin-section surface. Subsequently the inclusions were studied by cathodoluminescence (CL), reflected-light optical microscopy (ROM) and scanning electron microscopy (SEM). The aim of this study is to (i) identify phase compositions and spatial distribution of $\mathrm{H}_{2} \mathrm{O}$-soluble components in polycrystalline carbonate inclusions and (ii) study the aragonite-calcite dolomite relationships and (iii) discuss the possible origin of aragonite in the polycrystalline carbonate inclusions.

\section{Materials and methods}

\subsection{Experimental techniques}

Raman mapping was performed with a Kaiser System Hololab 5000R modular Raman microspectrometer (f/ 1.8). The microscope was fitted with a $100 \times$ objective (N.A. 0.75, W.D. $4.7 \mathrm{~mm}$ ). The samples were excited with approximately 45 to $50 \mathrm{~mW}$ net power on the sample of a $785 \mathrm{~nm}$ laser light from a diode laser. The scattered light was guided to the spectrograph through a confocal collection fibre with a numerical aperture of 0.15 . A backilluminated deep depletion Pelletier cooled CCD detector operating at $-70{ }^{\circ} \mathrm{C}$ was used for the detection of the scattered light. The Raman signal was collected in the spectral interval $100-1800 \mathrm{~cm}^{-1}$ with a spectral resolution of $4 \mathrm{~cm}^{-1}$. Further details of the calibration procedure can be found elsewhere (Hutsebaut et al., 2005). The laser spot size was $\sim 1 \mu \mathrm{m}$. The spectra were recorded with a $15 \mathrm{~s}$ accumulation time. After collection, the Raman spectra were processed in matlab with the Biodata toolbox (De Gussem et al., 2009). The Raman spectra were background-subtracted with the iterative polynomial fitting procedure described by Lieber \& Mahadevan-Jansen (2003) (200 iterations, fifth-order polynomial).

Cathodoluminescence (CL) microscopy study was carried out at University of Leuven, Belgium. The internal structures of polycrystalline carbonate inclusions were investigated under accelerating conditions of $18 \mathrm{kV}$ and $900 \mathrm{~mA}$.

Textural relations were examined in polished thin sections by reflected-light optical microscopy and back-scattered electron images on a Camebax electron microprobe (Electron Microscopy Unit, Université Catholique de Louvain-la-Neuve) and a JEOL 6380LA (Institute of Geology and Mineralogy SB RAS, Novosibirsk). The phase compositions were determined on a JEOL JXA8100 using an acceleration voltage of $15 \mathrm{kV}$ and a beam current of $1 \mathrm{nA}$ and on a Camebax electron microprobe using an acceleration voltage of $15 \mathrm{kV}$ and a beam current of $6 \mathrm{nA}$.

\subsection{Petrography}

The samples in this study belong to the carbonate-bearing garnet-pyroxene rocks of the diamondiferous Unit 1 of the Kokchetav Massif (Dobretsov et al., 1995; Korsakov \& Hermann, 2006; Ogasawara et al., 2000; Pechnikov \& Kaminsky, 2008; Shatsky et al., 1995; Schertl et al., 2004). Some diamondiferous garnet-pyroxene rocks have been considered to be isolated bodies within pelitic gneisses (Shatsky et al., 1995; Sobolev \& Shatsky, 1990). These rocks are closely associated with mainly diamondfree metacarbonate rocks. Although in some cases there is a contact between the diamond-free and the diamond-bearing samples, in general diamond spatial distribution is highly heterogeneous and diamond-bearing and diamondfree UHPM rocks may occur together. This study has 
focused mainly on an unusual composite sample (GAK101) containing variable proportions of carbonate and silicate minerals in different layers (Fig. 1).

Sample GAK101 consists of four different layers ranging from almost white (layer 1) over grey (layer 2 and 3) to green (layer 4) with variable amounts of carbonate minerals, garnet and clinopyroxene (Fig. 1a and Table 1). Grey layers are rich in sulphides (e.g., pyrite and pyrrhotite), Ti-clinohumite and serpentine pseudomorphs after forsterite. Dolomite was identified exclusively in layer 2
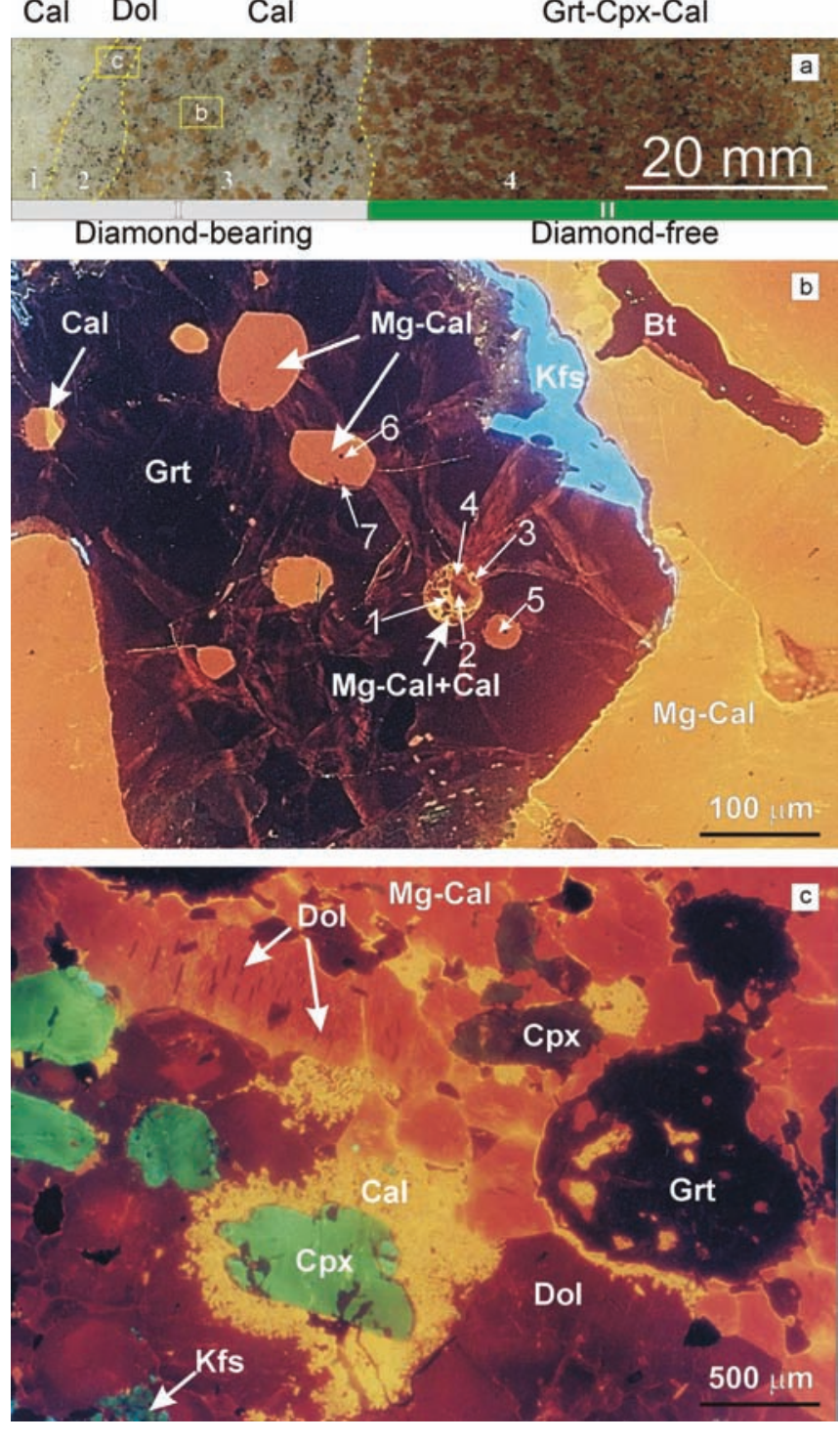

Fig. 1. (a) Photograph of the sample GAK101 showing four different layers. Layers 1, 2, and 3 consist of diamond-bearing Mg-bearing calcite and dolomite marble layers. Layer 4 is composed of diamondfree garnet-clinopyroxene rocks (detailed description of the different layers is presented in Table 1). I and II are the numbers of thin sections used in this study; the boxes indicate the position of the CL images of (b) and (c); dashed lines indicate boundaries between layers. (b-c) Representative CL images of matrix carbonates and carbonate-inclusions from calcite and dolomite marble, respectively. Arabic numbers and arrows mark the location of microprobe point analyses. Analyses are presented in Table 3.
(Fig. 1). Only the light-coloured, almost white, layer 1 contains accessory microdiamonds. The mineral assemblages from different layers and their specific features are presented in Table 1.

Polycrystalline carbonate inclusions up to $400 \mu \mathrm{m}$ in size predominantly appear within layer 3 (Fig. 1). They occur mainly in garnet and clinopyroxene porphyroblasts and have been found in zircon, as well (Korsakov et al., 2002). These carbonate inclusions closely resemble the polycrystalline carbonate inclusions that were interpreted to be crystallization products of UHPM carbonate melts (Korsakov \& Hermann, 2006). However, there exist significant differences between these two types of carbonate inclusions. Almost all magnesian-calcite polycrystalline inclusions display rounded shapes and sharp carbonategarnet interface. Contrary to the polycrystalline carbonate melt inclusions described by Korsakov \& Hermann (2006) neither diamond nor other phases (e.g., silicates) were identified within the aragonite-bearing polycrystalline carbonate inclusions studied here. The lack of dense radial crack patterns around the aragonite-bearing inclusions is another typical feature of this type of inclusions. The number of the subgrains within each polycrystalline inclusion varies significantly from inclusion to inclusion. Monocrystalline carbonate inclusions from diamond-bearing marbles and diamond-free garnet-clinopyroxene rock are abundant in garnet and clinopyroxene. There is no systematic spatial distribution of poly- and monocrystalline carbonate inclusions within the garnet-host.

Diamond and graphite exclusively occur in diamondbearing marbles, mainly as inclusions in K-bearing clinopyroxene and garnet porphyroblasts. Graphite was found (i) as inclusion in garnet and clinopyroxene (often together with diamond) and (ii) in the sample matrix itself. No graphite was found in the diamond-free part of the sample, despite thorough checking. This is consistent with the previously reported observation that sulphide-rich zones are diamond-free (Korsakov \& Hermann, 2006; Schertl et al., 2004).

\section{Results}

\subsection{Raman spectroscopic analysis}

Carbonates are distinguishable by their diagnostic Raman spectra (Bischoff et al., 1985; Burke, 2001; Gillet et al., 1993; Frost \& Dickfos, 2007; Liu \& Mernagh, 1990; Perraki et al., 2006; Scheetz \& White, 1977; Williams et al., 1992 and references therein). However, the pressure dependence of the vibration frequencies is well known only in the case of particular carbonates (Gillet et al., 1993). Because of the small sample volumes and the possibility to analyse unexposed inclusions, non-destructive Raman mapping is a very promising tool for the identification and study of the spatial distribution of carbonates (e.g., calcite, aragonite, dolomite, and magnesite) and $\mathrm{H}_{2} \mathrm{O}$-soluble minerals within inclusions. 
Table 1. Mineral assemblages and specific features of different layers of sample GAK101.

\begin{tabular}{|c|c|c|}
\hline Layers & Mineral assemblage & Specific features \\
\hline 1 (light-coloured) & $\begin{array}{l}\text { Mg-Cal, Grt, K-Cpx, Phl, } \\
\text { Cpx-II, Spl, Dia, Gr }\end{array}$ & $\begin{array}{l}\mathrm{Mg}-\mathrm{Cal} \text { (orange to yellow CL) as matrix and as inclusions in Grt and K-Cpx, K-Cpx } \\
\text { with abundant exsolution lamellae of Phl, Kfs }\end{array}$ \\
\hline 2 (grey-coloured) & $\begin{array}{l}\text { Mg-cal, Dol, Grt, Cpx, Ti- } \\
\text { Chu, Py, Po, Fo-pseud }\end{array}$ & $\begin{array}{l}\text { Dol-matrix (dark red CL), Mg-cal-matrix (orange CL) with Dol-exsolution lamellae } \\
\text { (dark red CL), K-Cpx with few exsolution lamellae of Phl, Kfs }\end{array}$ \\
\hline 3 (grey-coloured) & Mg-cal, Grt, K-Cpx, Py, Po & $\begin{array}{l}\text { Mg-cal-matrix (orange CL) rarely with Dol-exsolution lamellae (dark red CL), Mg-cal } \\
\text { inclusions in Grt and K-Cpx (orange to yellow, rare dark red CL), rare Ar inclusions } \\
\text { in Grt (no CL or very weak greenish CL, can be easily overlooked), K-Cpx with few } \\
\text { exsolution lamellae of Phl, Kfs }\end{array}$ \\
\hline 4 (green-coloured) & Grt, Cpx, Mg-Cal, Py, Ilm & Mg-cal (orange CL), Cpx with very weak or no CL \\
\hline
\end{tabular}

Mineral abbreviations according to Kretz (1983).

The two polymorphs of $\mathrm{CaCO}_{3}$, calcite and aragonite, were distinguished in the samples studied by their diagnostic Raman spectra (Fig. 2 and Table 2). Calcite is characterized by a strong band at $1086 \mathrm{~cm}^{-1}$, along with other weaker bands at 156,283 , and $713 \mathrm{~cm}^{-1}$ (Edwards et al., 2005). The main band of aragonite is also located at $1086 \mathrm{~cm}^{-1}$ with subsidiary bands at $154,181,191,208$, 249, 261, 273, 283, and $704 \mathrm{~cm}^{-1}$ (Edwards et al., 2005). Only the bands marked in italics were documented in this study. The host garnet is characterized by a strong band at

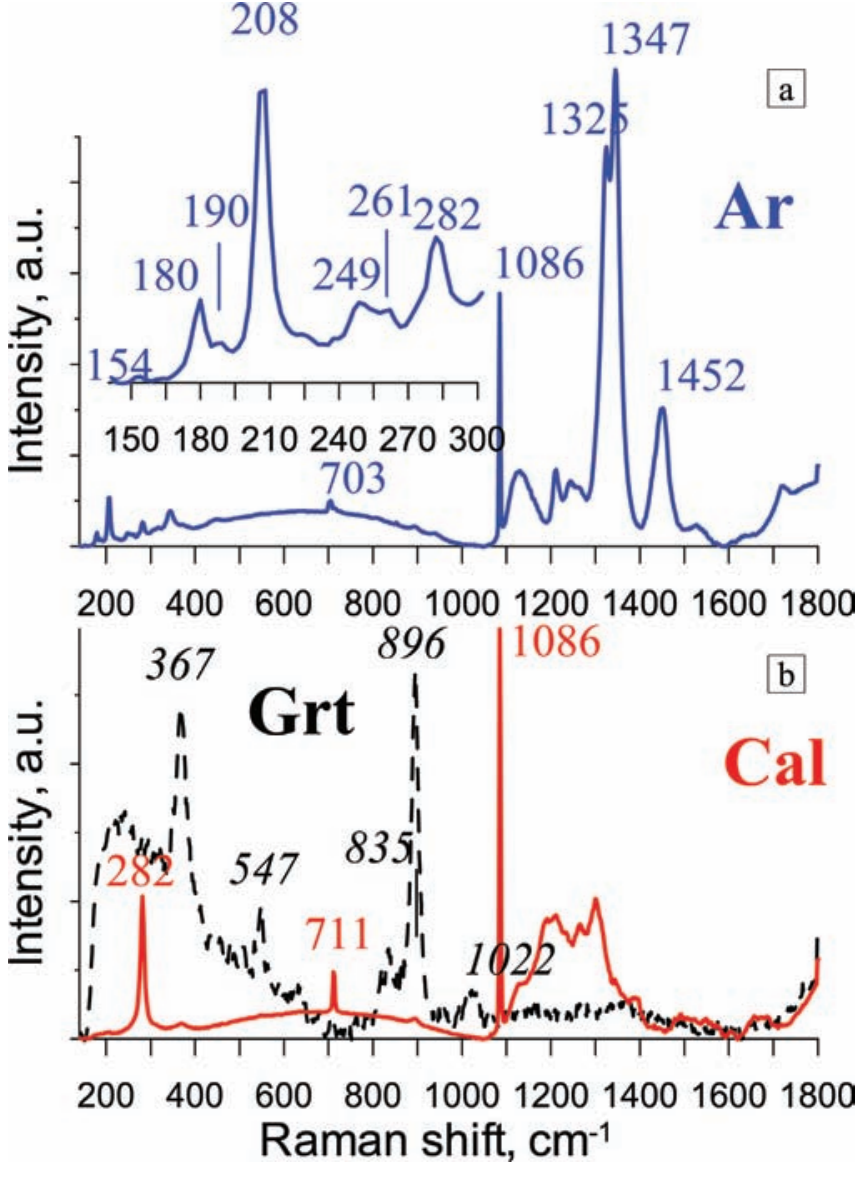

Fig. 2. Representative Raman spectra of (a) aragonite (blue spectrum) and (b) calcite (red spectrum), and garnet (black spectrum).
$896 \mathrm{~cm}^{-1}$, along with other weaker bands at $367,547,835$ and $1022 \mathrm{~cm}^{-1}$ (Fig. 2). A slight downshift of roughly 1 $\mathrm{cm}^{-1}$ in the $283 \mathrm{~cm}^{-1}$ calcite band was observed. A weak band at $282 \mathrm{~cm}^{-1}$ in the aragonite spectrum appears. Most likely this band is caused by very fine-grained calcitearagonite intergrowth, because the band at around 283 $\mathrm{cm}^{-1}$ in the Raman spectrum of aragonite is generally very weak (Edwards et al., 2005). Several additional very intense and rather narrow bands appear around 1325, 1347, and $1452 \mathrm{~cm}^{-1}$ in the aragonite spectrum (Fig. 2a). When excited with a different laser source $\left(\mathrm{Ar}^{+}, 514.5 \mathrm{~nm}\right)$ the aragonite exhibited no band at these positions. Thus, these bands are considered to be luminescent bands. Calcite also has several luminescent bands, but these are generally broader and less intense (Fig. 2b).

Raman mapping of a polycrystalline carbonate inclusion revealed mainly calcite and an area with bands typically assigned to aragonite (Fig. 3). The band position of aragonite and calcite corresponds to literature spectra obtained at ambient conditions (Fig. 2 and Table 2). The measured Raman band positions might also be slightly affected by the analytical conditions and exhibit slight differences compared to the literature ones (different calibration standards, slit width, gratings, etc.). It can thus be misleading to check whether minor Raman band shifts indicate residual overpressure inside the inclusion. When a subsurface inclusion is exposed at the surface through polishing, its residual pressure disappears. Hence, one inclusion was exposed at the thin section surface and reanalysed to detect residual pressures. The band positions of calcite and aragonite are equal to the positions of the intact inclusion. This observation implies that no measurable shifts of the main Raman band of calcite and aragonite in the polycrystalline inclusion were overlooked.

\subsection{Optical microscopy, cathodoluminescence and SEM-EDS studies}

Over 100 polycrystalline carbonate inclusions were analysed by CL and SEM. Polycrystalline carbonate inclusions (calcite or calcite and dolomite), exhibit a wide variety of textures observable either with the reflected-light microscope or in cathodoluminescence images (Fig. 1, 4 and 5). 
Table 2. Wavenumbers $\left(\mathrm{cm}^{-1}\right)$ of aragonite and calcite Raman bands in spectra of a representative unexposed polycrystalline inclusion.

\begin{tabular}{|c|c|c|c|c|c|c|c|}
\hline \multicolumn{4}{|c|}{ Calcite } & \multicolumn{4}{|c|}{ Aragonite } \\
\hline$v^{*}\left(\mathrm{~cm}^{-1}\right)$ & $(\mathrm{d} v / \mathrm{d} P)_{T}\left(\mathrm{~cm}^{-1} / \mathrm{GPa}\right)$ & $v\left(\mathrm{~cm}^{-1}\right)$ & $P(\mathrm{GPa})$ & $\begin{array}{c}v^{*}\left(\mathrm{~cm}^{-1}\right) \\
152\end{array}$ & $\begin{array}{c}(\mathrm{d} v / \mathrm{d} P)_{T}\left(\mathrm{~cm}^{-1} / \mathrm{GPa}\right) \\
2.7 \pm 0.2\end{array}$ & $\begin{array}{c}v\left(\mathrm{~cm}^{-1}\right) \\
154\end{array}$ & $\begin{array}{c}P(\mathrm{GPa}) \\
0.7\end{array}$ \\
\hline 156 & $2.47 \pm 0.3$ & 156 & $10^{-4}$ & 180 & $3.4 \pm 0.6$ & 180 & $10^{-4}$ \\
\hline 283 & $5.27 \pm 0.4$ & 282 & -0.19 & 206 & $3.3 \pm 0.5$ & 207 & 0.3 \\
\hline $\begin{array}{r}713 \\
1086\end{array}$ & $\begin{array}{l}2.22 \pm 0.2 \\
5.87 \pm 0.4\end{array}$ & $\begin{array}{r}713 \\
1086\end{array}$ & $\begin{array}{l}10^{-4} \\
10^{-4}\end{array}$ & 704 & $\begin{array}{l}1.5 \pm 0.1 \\
2.3 \pm 0.2\end{array}$ & 704 & $10^{-4}$ \\
\hline
\end{tabular}

Pressure shifts of the Raman modes of aragonite and calcite after Gillet et al. (1993). $v^{*}=$ theoretical, $v=$ measured in this study.
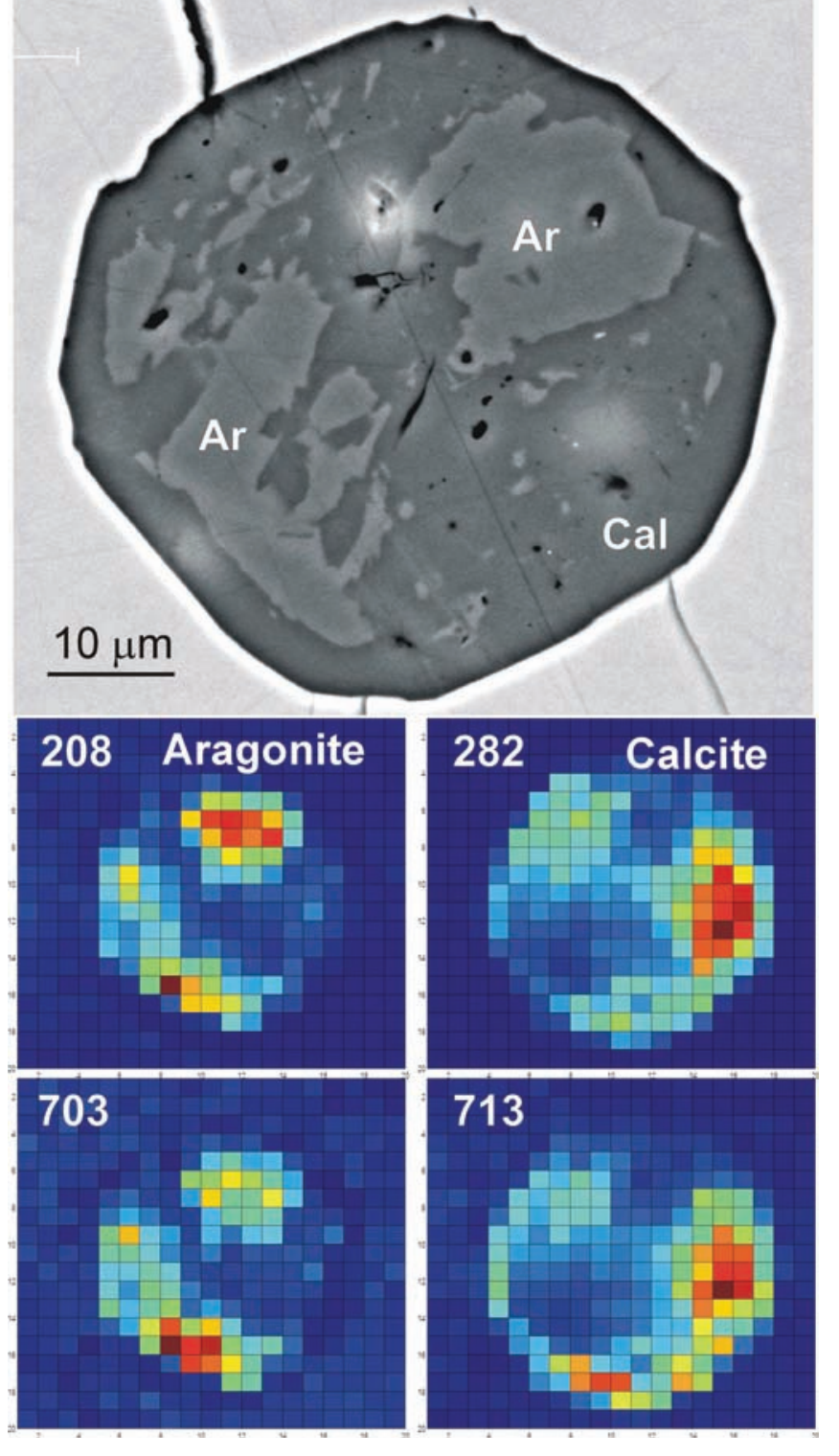

Fig. 3. BSE image and Raman maps of the polycrystalline carbonate inclusion presented in Fig. 4g-i.
Figure 4 shows that carbonate textures are variable and that blocky textures dominate. Monocrystalline magnesian-calcite inclusions occur intimately close to polycrystalline carbonate inclusions within a garnet porphyroblast. Many polycrystalline inclusions commonly show intricate compositional zoning as indicated by CL study (Fig. 1b). Brighter zones within polycrystalline inclusions contain higher $\mathrm{Sr}$ content up to $0.5 \mathrm{wt} \%$, whereas darker zones are richer in $\mathrm{Fe}, \mathrm{Mn}$ and $\mathrm{Mg}$. In calcites, $\mathrm{Mn}$ is generally considered to be the main CL activator (Marshall, 1988) although electron microprobe analyses indicate that many other elements are also present and a simple relationship between CL intensity and Mn concentration is therefore lacking. All investigated aragonite-bearing inclusions are characterised by an extremely weak CL pattern. A very weak greenish colour of CL was documented in only one case (Fig. 5c). Interestingly, the calcite coexisting with aragonite within the same inclusion shows also very weak luminescence. Some polycrystalline carbonate inclusions contain fine-grained dirty aggregates with high interference colours (Fig. 5a, b). Calcite coexisting with aragonite, at least on an optical basis, behaves as a monocrystal, although the orientation of aragonite is often different from the orientation of calcite. Furthermore, no crack patterns associated with these inclusions were found. Cracks only appeared during the final polishing of the sample to expose the inclusion at the thin-section surface. SEM study of the polycrystalline carbonate inclusions revealed that they are rather heterogeneous (Fig. 3), confirming the results of CL imaging. In back-scattered electron (BSE) images, calcite exhibits different shades of grey with brighter parts rich in $\mathrm{Mg}, \mathrm{Mn}$ and $\mathrm{Fe}$ and darker areas rich in Sr (Table 3).

Three different carbonates can be distinguished on the basis of their CL images: calcite, dolomite, and aragonite. Calcite can be further distinguished into different generations: orange $\mathrm{Mg}$-bearing calcite, bright-yellow secondary pure calcite (Fig. 1c), dark-yellow calcite enriched in $\mathrm{Sr}$ (Fig. 1b) and dark-orange to red calcite enriched in Fe, Mn, and $\mathrm{Mg}$ (Fig. 5). Dolomite appears dark red. Dolomite and Mg-bearing calcite form distinct layers (Fig. 1) and are the dominant carbonate minerals. Aragonite does not produce CL or only very weak greenish CL. The garnet and pyroxene crystals contain rare carbonate inclusions exhibiting yellow to orange luminescence. Microprobe analyses 

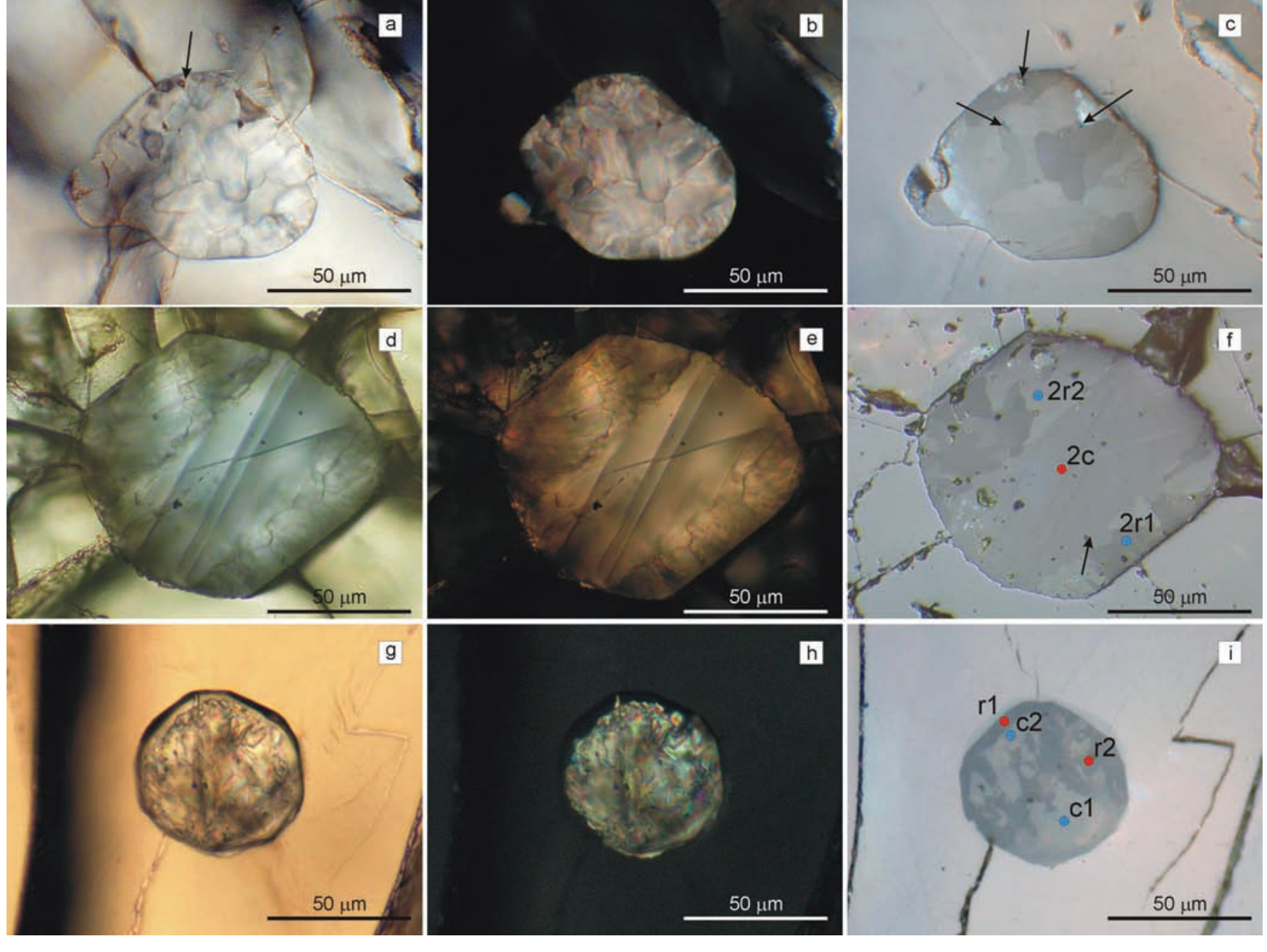

Fig. 4. Plane-polarized (a, d, g), cross-polarized (b, e, h), and reflected light (c, f, i) photomicrographs of a polycrystalline carbonate inclusions in garnet with representative textures of polycrystalline carbonate inclusions with blocky - granular (a, b, c) and fibrous-like (d, e, f) textures. Arrows in reflected-light photographs indicate cavities and holes. Numbered blue and red points correspond to the microprobe analyses given in Table 3 .

proved that the yellow inclusions are nearly $\mathrm{Mg}$-free $\mathrm{CaCO}_{3}\left(\mathrm{Ca}_{0.98} \mathrm{Mg}_{0.02} \mathrm{CO}_{3}\right)$, whereas (i) the Mg-bearing calcite (orange luminescent) is $\mathrm{Ca}_{0.95} \mathrm{Mg}_{0.04} \mathrm{Fe}_{0.01} \mathrm{CO}_{3}$ and (ii) dolomite (dark red luminescent) is $\mathrm{Ca}_{0.50} \mathrm{Mg}_{0.49} \mathrm{Fe}_{0.01} \mathrm{CO}_{3}$. Sometimes dolomite exsolution patterns were identified within Mg-bearing calcite (Fig. 1c). Similar features were observed by Ogasawara et al. (2000) and Schertl et al. (2004).

\section{Discussion}

\subsection{Origin of aragonite in $\mathrm{UH} P \mathrm{M}$ rocks}

Aragonite in the polycrystalline carbonate inclusions occurs as fine-grained "dirty" aggregates, whereas calcite tends to form clean coarser-grained aggregates (Fig. 4 and 5). In the aragonite-bearing inclusion of Fig. 4, the clean shell, consisting of calcite, optically appears as a monocrystal. In the case of an UHPM origin of aragonite and later calcite formation by partial replacement of aragonite during retrograde metamorphism, the opposite would have been expected, i.e. monocrystalline aragonite surrounded by polycrystalline fine-grained calcite. It has been reported that newly formed minerals, replacing other minerals or forming pseudomorphs after them, are generally more fine-grained compared to the reactant minerals. In the coesite-to-quartz transformation in metamorphic rocks (Chopin, 1984; Smith, 1984) rather large relics of coesite are preserved within fine-grained quartz aggregates. In general, relics of coesite partly transformed to quartz are characterized by radial growth of polycrystalline quartz around a coesite core and radial fractures in the surrounding host mineral. These cracks result from the different elastic properties of the inclusion and the host mineral and the significant volume change related to the coesite-to-quartz transformation (Chopin, 1984; Gillet et al., 1984; Smith, 1984; Van der Molen \& van Roermund, 1986). 

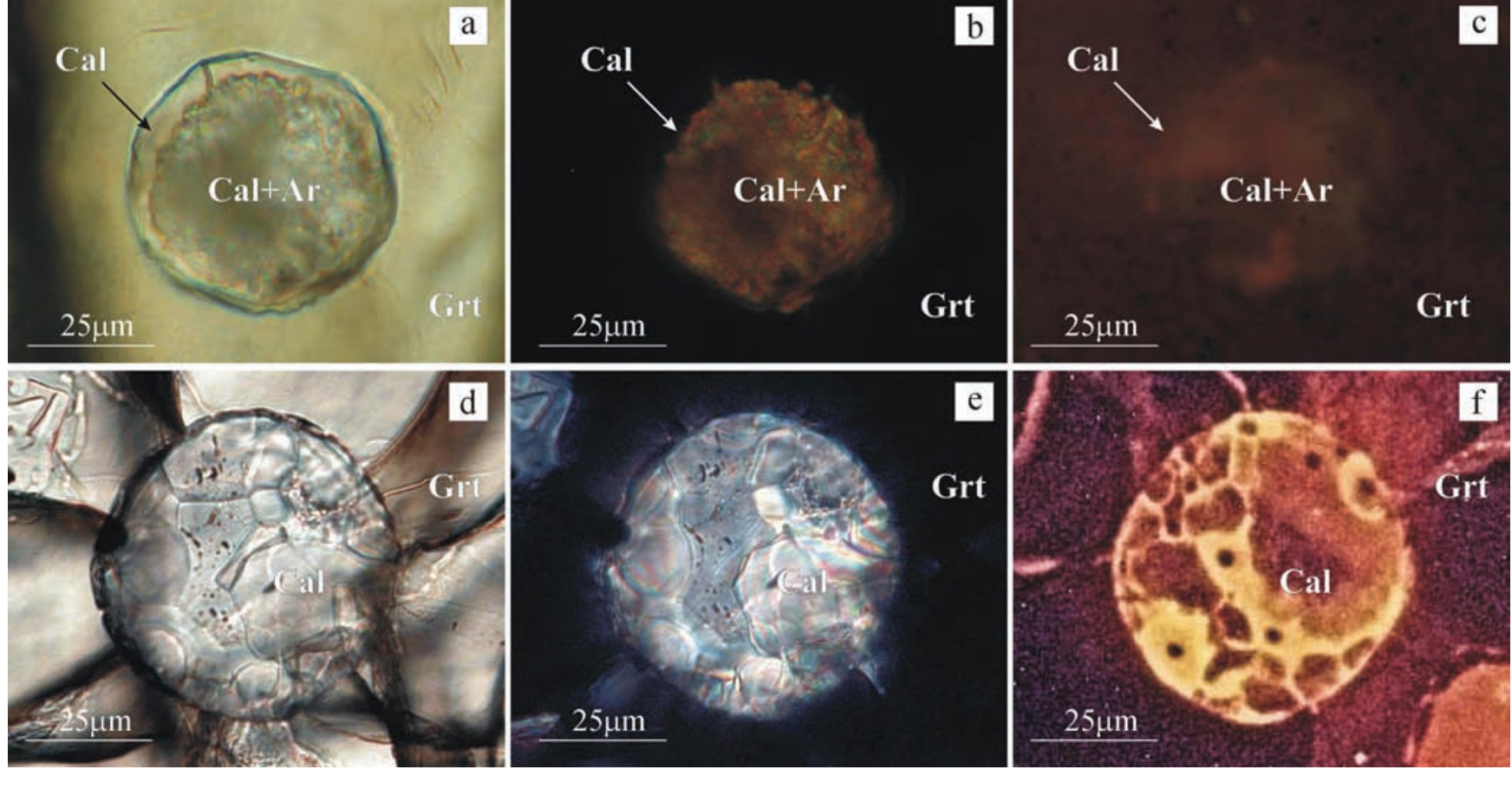

Fig. 5. Photomicrographs of (a-b) aragonite-bearing sample GAK101 and (c-d) polycrystalline carbonate melt inclusions in garnet sample G0. (a) and (c) are plane-polarized light, (b) cross-polarized, and (d) CL photographs. The CL colour and intensity of calcite varies from orange to dark red (enriched in $\mathrm{Fe}, \mathrm{Mn}, \mathrm{Mg}$ ), and the yellow zones are enriched in $\mathrm{Sr}$.

The lack of magnesite in the polycrystalline carbonate inclusions studied here and the coexistence of fine-grained aragonite aggregates with coarse-grained calcite aggregates indicate that aragonite could not be formed by the breakdown of dolomite to magnesite and aragonite.

Alternatively, aragonite may be formed by recrystallization of a highly strained calcite grain. Such mechanism was proposed for aragonitic marbles (Vance, 1968) and documented in experiments (Newton et al., 1969). The transformation of calcite to aragonite would also reduce the residual pressure.

Raman spectra of both calcite and aragonite correspond well with Raman spectra obtained at ambient conditions. This indicates that there is no overpressure inside the inclusions: their residual pressure can be estimated as high as one atmosphere. Pressure and temperature dependence of the main calcite and aragonite bands is rather well established (Gillet et al., 1993) and can be used for the

Table 3. Representative electron-microprobe analyses (wt \%) of the polycrystalline aragonite and calcite inclusions presented in Fig. 1 and 4 (sample GAK101).

\begin{tabular}{|c|c|c|c|c|c|c|c|c|c|c|c|c|c|c|}
\hline \multirow[b]{2}{*}{ No. } & \multicolumn{3}{|c|}{ Inclusion-I } & \multicolumn{4}{|c|}{ Inclusion-II } & \multicolumn{7}{|c|}{ Inclusion-III } \\
\hline & $\begin{array}{l}\mathrm{c} 1 \\
\mathrm{Ar}\end{array}$ & $\begin{array}{l}\mathrm{c} 2 \\
\mathrm{Ar}\end{array}$ & $\begin{array}{l}\mathrm{r} 1 \\
\mathrm{Cal}\end{array}$ & $\begin{array}{l}\mathrm{r} 2 \\
\mathrm{Cal}\end{array}$ & $\begin{array}{l}2 \mathrm{c} \\
\mathrm{Cal}\end{array}$ & $\begin{array}{l}2 \mathrm{r} 1 \\
\mathrm{Ar}\end{array}$ & $\begin{array}{l}2 \mathrm{r} 2 \\
\mathrm{Ar}\end{array}$ & 1 & 2 & 3 & 4 & 5 & 6 & 7 \\
\hline $\mathrm{SiO}_{2}$ & 0.02 & 0.00 & 0.00 & 0.03 & 0.01 & 0.01 & 0.00 & 0.00 & 0.01 & 0.01 & 0.00 & 0.00 & 0.01 & 0.00 \\
\hline $\mathrm{TiO}_{2}$ & 0.01 & 0.00 & 0.00 & 0.01 & 0.00 & 0.00 & 0.01 & 0.00 & 0.00 & 0.00 & 0.01 & 0.00 & 0.00 & 0.01 \\
\hline $\mathrm{Al}_{2} \mathrm{O}_{3}$ & 0.01 & 0.01 & 0.01 & 0.03 & 0.00 & 0.01 & 0.02 & 0.00 & 0.00 & 0.01 & 0.02 & 0.00 & 0.01 & 0.02 \\
\hline $\mathrm{FeO}$ & 0.12 & 0.16 & 0.25 & 0.17 & 0.22 & 0.06 & 0.09 & 0.11 & 0.11 & 0.06 & 0.27 & 0.34 & 0.30 & 0.08 \\
\hline $\mathrm{MgO}$ & 0.00 & 0.00 & 0.00 & 0.00 & 0.48 & 0.00 & 0.00 & 0.07 & 0.00 & 0.04 & 0.07 & 0.08 & 0.08 & 0.00 \\
\hline $\mathrm{MnO}$ & 0.00 & 0.01 & 0.00 & 0.01 & 0.01 & 0.00 & 0.00 & 0.00 & 0.02 & 0.02 & 0.69 & 1.23 & 0.99 & 0.00 \\
\hline $\mathrm{CaO}$ & 56.3 & 56.0 & 56.5 & 57.6 & 55.8 & 57.5 & 57.1 & 56.0 & 56.8 & 56.3 & 56.2 & 56.2 & 57.5 & 56.4 \\
\hline $\mathrm{Na}_{2} \mathrm{O}$ & 0.01 & 0.00 & 0.01 & 0.00 & 0.03 & 0.00 & 0.00 & 0.00 & 0.00 & 0.00 & 0.00 & 0.01 & 0.02 & 0.00 \\
\hline $\mathrm{K}_{2} \mathrm{O}$ & 0.00 & 0.00 & 0.00 & 0.00 & 0.00 & 0.00 & 0.00 & 0.01 & 0.01 & 0.00 & 0.00 & 0.00 & 0.01 & 0.00 \\
\hline $\mathrm{SrO}$ & 0.11 & 0.14 & 0.10 & 0.01 & 0.00 & 0.08 & 0.07 & 0.09 & 0.30 & 0.11 & 0.17 & 0.14 & 0.17 & 0.57 \\
\hline $\mathrm{BaO}$ & 0.00 & 0.00 & 0.02 & 0.00 & 0.07 & 0.00 & 0.03 & 0.00 & 0.00 & 0.07 & 0.00 & 0.00 & 0.05 & 0.00 \\
\hline Total & 56.60 & 56.28 & 56.88 & 57.83 & 56.60 & 57.67 & 57.32 & 56.26 & 60.95 & 61.11 & 61.23 & 59.80 & 59.09 & 59.64 \\
\hline
\end{tabular}


estimation of the residual pressure in the carbonate inclusions in the garnet porphyroblast. Residual pressures in other inclusions (e.g., coesite) within host minerals for the similar UHPM lithologies have been estimated as high as $2.2 \mathrm{GPa}$ (Korsakov et al., 2007; Parkinson \& Katayama, 1999; Ye et al., 2001).

The lack of significant shifts in the main bands of both aragonite and calcite indicates very low residual pressure in the aragonite-calcite inclusions. Numerical modelling using elastic constants for aragonite and calcite inclusions and the host garnet allows us to estimate the $P$ - $T$ conditions at which aragonite was captured (Fig. 6). Assuming that peak metamorphic conditions were $P=6 \mathrm{GPa}$ and $T=1000{ }^{\circ} \mathrm{C}$ (Korsakov \& Hermann, 2006; Shatsky et al., 1995) and that aragonite in inclusions never transformed to calcite, the residual pressure in the inclusions is estimated as high as $1.7 \mathrm{GPa}$. In the case of aragonite-tocalcite transformation the residual pressure would have been increased to $4.5 \mathrm{GPa}(\alpha=0.5)$. Taking into account the higher peak metamorphic conditions reported by Ota et al. (2000) and Massonne (2003), the residual pressure would have been expected even higher (Fig. 6).

Using different hypothetical values for residual pressures $\left(e . g ., P_{\text {in }}=0.001,0.01\right.$, and $\left.0.1 \mathrm{GPa}\right)$ we calculated $P_{0}$ as function of $T_{0}$ (Fig. 6). The results of this modelling reveal that the aragonite inclusions could have been captured only at pressures significantly lower than those of the peak metamorphic conditions, close to the aragonite-calcite equilibrium line. Lack of information on the residual pressure of aragonite inclusions in diamond (Dobrzhinetskaya et al., 2006), does not allow us to check whether aragonite was captured in the dolomite stability field (at $P 6 \mathrm{GPa}$ ) or not.

This is inconsistent with a model for the origin of polycrystalline calcite inclusions by partial or complete transformation, since in that case significant overpressure should be expected. This was observed in the case of coesite inclusions in different minerals (Korsakov et al., 2007; Parkinson \& Katayama, 1999; Ye et al., 2001).

Aragonite-bearing inclusions are characterized by very weak CL patterns (Fig. 5c). Hence, they can be easily overlooked, unless these inclusions are checked with Raman spectroscopy. Contrary to aragonite-bearing inclusions, former melt inclusions described by Korsakov \& Hermann (2006) have very strong luminescence (Fig. 5e), which can be used as a diagnostic feature. The absence of any other carbonate (e.g., alkaline carbonates or magnesite) besides calcite and aragonite in the unexposed polycrystalline inclusions indicates that cavities and holes on the polished surface of these inclusions are related with crushing of fine-grained aggregates. CL and SEM studies of the polycrystalline inclusions show that they predominantly consist of coarse-grained aggregates of calcite. The distribution of impurities (e.g., $\mathrm{Mg}, \mathrm{Sr}, \mathrm{Mn}$, and $\mathrm{Fe}$ ) within the inclusions is highly heterogeneous.

The formation of aragonite by the breakdown of dolomite is unlikely, because so far polycrystalline carbonate inclusions have been identified in calcite marbles (Korsakov \& Hermann, 2006). Low values of residual

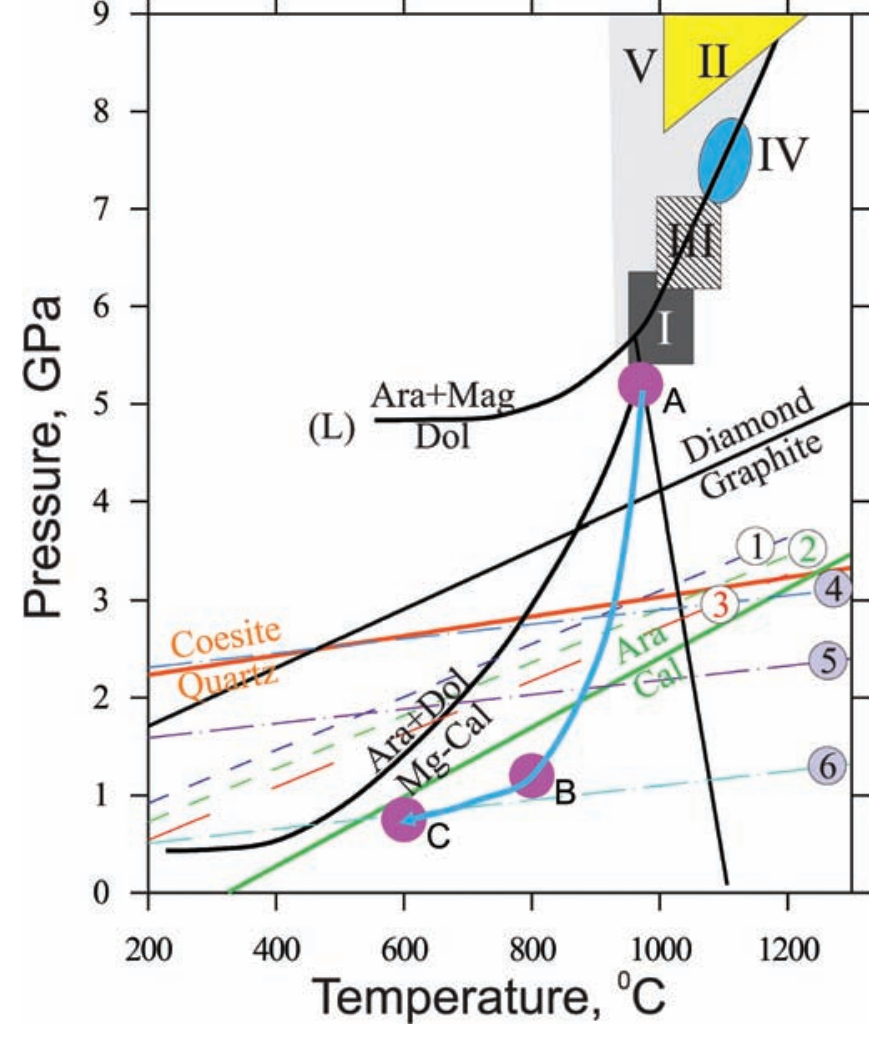

Fig. 6. Peak metamorphic conditions for diamondiferous calc-silicate rocks and marbles from the Kokchetav Massif: I-Okamoto et al. (2000); Ogasawara et al. (2000), II-Zhu \& Ogasawara (2002), IIIOgasawara et al. (2002), IV-Massonne (2003), V-Dobrzhinetskaya et al. (2006). Experimental phase relations for dolomitic carbonates after Goldsmith \& Newton (1969), Irving \& Wyllie (1975), Luth (2001), Buob et al. (2006), and Hermann (2003a). Experimental study (L) of Luth (2001) on the reaction dolomite (dol) = aragonite (ara) + magnesite (mag). Graphite-diamond and coesite-quartz transitions are from Kennedy \& Kennedy (1976) and Mirwald \& Massonne (1980). The retrograde evolution shown as (A)-(C) is taken from Hermann et al. (2001). Aragonite inclusion without phase transformation to calcite: $1-3$, dependence of $P_{0}$ as function of $T_{0}$ for $P_{\text {in }}=0.1,0.01$ and 0.001 respectively; Calcite inclusion without transformation to aragonite: $4-6$, residual pressure $\left(P_{\text {in }}\right)$ as function of $T_{0}$ for $P_{0}=6,4$ and $3 \mathrm{GPa}$, respectively.

pressure in aragonite-bearing inclusions are inconsistent with their UHPM origin. This fact can be explained by different models. First of all, aragonite could have been formed during prograde metamorphic events at relatively low $P$-T parameters. Ogasawara et al. (2000) proposed that the subduction path of the Kokchetav Massif should cross the aragonite stability field. Thus, aragonite rather than calcite or magnesian calcite should be the stable $\mathrm{CaCO}_{3}$ polymorph up to peak metamorphic conditions; protected by the host garnet these inclusions would not react during all subsequent transformations ( $c f$. Chopin et al., 2008). The rarity of aragonite in UHPM samples can be associated with very fast transformation (even faster than coesite-to-quartz) to calcite during the retrograde stage. However, the possibility that aragonite has been simply overlooked is high. The same very low residual pressure 
would occur if original inclusions were captured as a carbonate melt. Crystallization of aragonite was recently confirmed in $\mathrm{H} P$ and $\mathrm{H} T$ experiments (Sokol et al., 2001). Aragonite was found to be in equilibrium with diamond and carbonate melts. Fine-grained aggregates of aragonite were also identified in the quenching run products. Therefore, the origin of aragonite by crystallization of UHPM carbonate melts could be an important mechanism in some natural deeply subducted samples. However, the time and the exact $P-T$ conditions of the aragonite formation remain poorly defined.

\section{Concluding remarks}

The Raman spectroscopy study of polycrystalline carbonate inclusions in diamond-grade metamorphic rocks from the Kokchetav Massif, Northern Kazakhstan, revealed the presence of aragonite along with calcite. The aragonite-bearing polycrystalline inclusions exhibit different features compared to other polycrystalline inclusions, interpreted as crystallization products of UHPM carbonate melts. Aragonite appears within the inclusions as "dirty" chaotically oriented materials surrounded by a "clean" and monocrystalline calcite shell. Melt inclusions generally have different shapes of grain boundaries between sub-individuals within the inclusions; boundaries are generally smooth and convexoconcave. Grain boundaries between the host-garnet and the aragonite-bearing inclusions also differ from those between the host garnet and the melt inclusions; the former has a smooth garnet-carbonate interface, whereas the latter are often characterized by wavy or amoeboid shape. The melt inclusions are surrounded by rather dense radial crack patterns, whereas no such patterns appear around aragonitebearing inclusions; tiny cracks that are rarely observed appeared during polishing.

The lack of radial cracks around the polycrystalline carbonate inclusions and the absence of a measurable shift in the main Raman bands clearly indicate that the residual pressure within aragonite-bearing inclusions is minor. These features are inconsistent with an origin of aragonite at peak metamorphic conditions ( $\sim 6 \mathrm{GPa})$ by dolomite decomposition. Therefore, the presence of aragonite in diamond-bearing or diamond-grade UHPM rocks cannot be an unequivocal evidence for extremely deep subduction.

Acknowledgements: The authors thank Prof. Dr. Rudy Swennen and Dr. Anneleen Foubert (Katholieke Universiteit Leuven, Belgium) for their help in the CL analyses. This study was supported by the Russian Foundation for Basic Research (07-05-00072-a, 07-0500308-a), MK-259.2008.5, Russian Science Support Foundation. K.D.G. acknowledges the support of the Special Research Fund UGent (01P02107). We are also grateful to Prof. Dr. David Smith and Prof. Dr. Yoshihide Ogasawara for their careful and helpful reviews.

\section{References}

Bischoff, W.D., Sharma, S.K., Mackenzie, F.T. (1985): Carbonate ion disorder in synthetic and biogenic magnesian calcites: a Raman spectral study. Am. Mineral. 70, 581-589.

Buob, A., Luth, R.W., Schmidt, M.W., Ulmer, P. (2006): Experiments on $\mathrm{CaCO}_{3}-\mathrm{MgCO}_{3}$ solid solutions at high pressure and temperature. Am. Mineral., 91, 435-440.

Burke, E.A.J. (2001): Raman microspectrometry of fluid inclusions. Lithos, 55, 139-158.

Chopin, C. (1984): Coesite and pure pyrope in high-grade blueschists of western Alps: a first record and some consequences. Contrib. Mineral. Petrol., 86, 107-118.

Chopin, C, Beyssac, O., Bernard, S., Malavieille, J. (2008): Aragonite-grossular intergrowths in eclogite-facies marble, Alpine Corsica. Eur. J. Mineral., 20, 857-865.

De Gussem, K., De Gelder, J., Vandenabeele, P., Moens, L. (2009): The Biodata toolbox for MATLAB. Chemometr. Intell. Lab. Syst., 95, 49-52.

Dobretsov, N.L., Sobolev, N.V., Shatsky, V.S., Coleman, R.G., Ernst, W.G. (1995): Geotectonic evolution of diamondiferous paragneisses of the Kokchetav complex, Northern Kazakhstan the geologic enigma of ultrahigh-pressure crustal rocks within Phanerozoic foldbelt. Island Arc, 4, 267-279.

Dobrzhinetskaya, L.F., Wirth, R., Green II, H.W. (2006): Nanometric inclusions of carbonates in Kokchetav diamonds from Kazakhstan: a new constraint for the depth of metamorphic diamond crystallization. Earth Planet. Sci. Lett., 243, 85-93.

Edwards, H., Villar, S., Jehlicka, J., Munshi, T. (2005): FT-Raman spectroscopic study of calcium-rich and magnesium-rich carbonate minerals. Spectrochim. Acta A, 61, 2273-2280.

Frost, R.L. \& Dickfos, M. (2007): Hydrated double carbonates - a Raman and infrared spectroscopic study. Polyhedron, 26, 4503-4508.

Gillet, P., Ingrin, J., Chopin, C. (1984): Coesite in subducted continental crust: P-T history deduced from an elastic model. Earth Planet. Sci. Lett., 70, 426-436.

Gillet, P., Biellmann, C., Reynard, B., McMillan, P. (1993): Raman Spectroscopic studies of carbonates part I: high-pressure and high-temperature behaviour of calcite, magnesite, dolomite and aragonite. Phys. Chem. Minerals, 20, 1-18.

Goldsmith, J.R. \& Newton, R.C. (1969): P-T-X relations in the system $\mathrm{CaCO}_{3}-\mathrm{MgCO}_{3}$ at high temperatures and pressures. Am. J. Sci., 267A, 160-190.

Hermann, J. (2002): Experimental constraints on phase relations in subducted continental crust. Contrib. Mineral. Petrol., 143, 219-235.

- (2003a): Carbon recycled into deep Earth: evidence from dolomite dissociation in subduction-zone rocks: comment and reply. Geology, e4-e5.

- (2003b): Experimental evidence for diamond-facies metamorphism in the Dora-Maira Massif. Lithos, 70, 163-182.

Hermann, J. \& Green, D.H. (2001): Experimental constraints on high pressure melting in subducted crust. Earth Planet. Sci. Lett., 188, 149-186.

Hermann, J., Rubatto, D., Korsakov, A., Shatsky, V.S. (2001): Multiple zircon growth during fast exhumation of diamondiferous, deeply subducted continental crust (Kokchetav massif, Kazakhstan). Contrib. Mineral. Petrol., 141, 66-82.

Hutsebaut, D., Vandenabeele, P., Moens, L. (2005): Evaluation of an accurate calibration and spectral standardization procedure for Raman spectroscopy. Analyst, 130, 1204-1214. 
Hwang, S.-L., Shen, P., Chu, H.-T., Yui, T.-F., Lin, C.-C. (2001): Genesis of microdiamonds from melt and associated multiphase inclusions in garnet of ultrahigh-pressure gneiss from Erzgebirge, Germany. Earth Planet. Sci. Lett., 188, 9-15.

Hwang, S.-L., Shen, P., Chu, H.-T., Yui, T.-F., Liou, J.G., Sobolev, N.V., Zhang, R.-Y., Shatsky, V.S., Zayachkovsky, A. (2004): Kokchetavite: a new potassium-feldspar polymorph from the Kokchetav ultrahigh-pressure terrane. Contrib. Mineral. Petrol., 148, 380-389.

Hwang, S.-L., Shen, P., Chu, H.-T., Yui, T.-F., Liou, J.G., Sobolev, N.V., Shatsky, V.S. (2005): Crust-derived potassic fluid in metamorphic microdiamond. Earth Planet. Sci. Lett., 231, 295-306.

Irving, J.A. \& Wyllie, P.J. (1975): Subsolidus and melting relationships for calcite, magnesite and the join $\mathrm{CaCO}_{3}-\mathrm{MgCO}_{3}$ to 36 kb. Geochim. Cosmochim. Acta, 39, 35-53.

Katayama, I., Maruyama, S., Parkinson, C.D., Terada, K., Sano, Y. (2001): Ion micro-probe U-Pb zircon geochronology of peak and retrograde stages of ultrahigh-pressure metamorphic rocks from the Kokchetav massif, northern Kazakhstan. Earth Planet. Sci. Lett., 188, 185-198.

Kennedy, C.S. \& Kennedy, G.C. (1976): The equilibrium boundary between graphite and diamond. J. Geophys. Res., 81, 2467-2470.

Korsakov, A.V. \& Hermann, J. (2006): Silicate and carbonate melt inclusions associated with diamonds in deeply subducted carbonate rocks. Earth Planet. Sci. Lett., 241, 104-118.

Korsakov, A.V., Shatsky, V.S., Sobolev, N.V., Zayachkovsky, A.A. (2002): Garnet-biotite-clinozoisite gneisses: a new type of diamondiferous metamorphic rocks of the Kokchetav massif. Eur. J. Mineral., 14, 915-929.

Korsakov, A.V., Theunissen, K., Smirnova, L.V. (2004): Intergranular diamonds derived from partial melting of crustal rocks at ultrahigh-pressure metamorphic conditions. Terra Nova, 16, 146-151.

Korsakov, A.V., Vandenabeele, P., Theunissen, K. (2005): Discrimination of metamorphic diamond populations by Raman spectroscopy (Kokchetav, Kazakhstan). Spectrochim. Acta A, 61, 2378-2385.

Korsakov, A.V., Theunissen, K., Kozmenko, O.A., Ovchinnikov, Y.I. (2006): Reaction textures in clinozoisite gneisses. Russ. Geol. Geophys., 47, 497-510.

Korsakov, A.V., Hutsebaut, D., Theunissen, K., Vandenabeele, P., Stepanov, A.S. (2007): Raman mapping of coesite inclusions in garnet from the Kokchetav Massif (Northern Kazakhstan). Spectrochim. Acta A, 68, 1046-1052.

Kretz, R. (1983): Symbols for rock-forming minerals. Am. Mineral., 68, 277-279.

Langenhorst, F. (2003): Nanostructures in ultrahigh-pressure metamorphic coesite and diamond: a genetic fingerprint. Mitt. Österr. Mineral. Ges., 148, 401-412.

Lappin, M.A. \& Smith, D.C. (1981): Carbonate, silicate and fluid relationships in eclogites, Selje District and environs, SW Norway. Trans. Roy. Soc. Edinburgh, 72, 171-193.

Lieber, C.A. \& Mahadevan-Jansen, A. (2003): Automated method for subtraction of fluorescence from biological Raman spectra. Appl. Spectrosc., 57, 1363-1367.

Liu, L.-G. \& Mernagh, T.P. (1990): Phase transitions and Raman spectra of calcite at high pressures and room temperature. Am. Mineral., 75, 801-806.

Luth, R.W. (2001): Experimental determination of the reaction aragonite + magnesite $=$ dolomite at 5 to $9 \mathrm{GPa}$. Contrib. Mineral. Petrol., 141, 222-232.
Marshall, D.J. (1988): Cathodoluminescence of geological materials. Unwin Hyman, Boston.

Massonne, H.-J. (2003): A comparison of the evolution of diamondiferous quartz- rich rocks from the Saxonian Erzgebirge and the Kokchetav massif: are so-called diamondiferous gneisses magmatic rocks? Earth Planet. Sci. Lett., 216, 347-364.

Mirwald, P.M. \& Massonne, H.J. (1980): The low-high quartz-coesite transition to $40 \mathrm{kbar}$ between $600^{\circ} \mathrm{C}$ and $1600^{\circ} \mathrm{C}$ and some reconnaissance on the effect of $\mathrm{NaAlO}_{2}$ component on the low quartz-coesite transition. J. Geophys. Res., 85, 6983-6990.

Newton, R.C., Goldsmith, J.R., Smith, J.V. (1969): Aragonite crystallization from strained calcite at reduced pressures and its bearing on aragonite in low-grade metamorphism. Contrib. Mineral. Petrol., 22, 335-348.

O'Brien, P.J. \& Ziemann, M.A. (2008): Preservation of coesite in exhumed eclogite: insights from Raman mapping. Eur. J. Mineral., 20, 827-834.

Ogasawara, Y., Fukasawa, K., Maruyama, S. (2002): Coesite exsolution from supersilicic titanite in UHP marble from the Kokchetav massif, northern Kazakhstan. Am. Mineral., 87, 454-461.

Ogasawara, Y., Ohta, M., Fukasawa, K., Katayama, I., Maruyama, S. (2000): Diamond-bearing and diamond-free metacarbonate rocks from Kumdy-Kol in the Kokchetav massif, northern Kazakhstan. Island Arc, 9, 400-416.

Okamoto, K., Liou, J.G., Ogasawara, Y. (2000): Petrology of the diamond-grade eclogite in the Kokchetav Massif, northern Kazakhstan. Island Arc, 9, 379-399.

Ota, T., Terabayasgi, M., Parkinson, C.D., Masago, H. (2000): Thermobaric structure of the Kokchetav ultrahigh-pressure-high-pressure massif deduced from a north south transect in the Kulet and Saldat-Kol regions, northern Kazakhstan. Island Arc, 9, 328-357.

Parkinson, C.D. \& Katayama, I. (1999): Present-day ultrahigh-pressure conditions of coesite inclusions in zircon and garnet: evidence from laser Raman microspectroscopy. Geology, 27, 979-982.

Pechnikov, V.A. \& Kaminsky, F.V. (2008): Diamond potential of metamorphic rocks in the Kokchetav massif, northern Kazakhstan. Eur. J. Mineral., 20, 395-413.

Perraki, M., Proyer, A., Mposkos, E., Kaindl, R., Hoinkes, G. (2006): Raman micro-spectroscopy on diamond, graphite and other carbon polymorphs from the ultrahigh-pressure metamorphic Kimi complex of the Rhodope Metamorphic Province, NE Greece. Earth Planet. Sci. Lett., 241, 672-685.

Perraki, M., Smith, D.C., Mposkos, E. (2007): The luminescent carbon-bearing microinclusion enigma in the Kimi Unit, Rhodope, Greece: Raman microscopic point analyses and mapping with different lasers. Spectrochim. Acta A, 68, 1077-1084.

Perraki, M., Korsakov, A.V., Smith, D.C., Mposkos, E. (2009): Raman spectroscopic and microscopic criteria for the distinction of microdiamonds in ultrahigh-pressure metamorphic rocks from diamond in sample preparation materials. Am. Mineral., 94, 546-556.

Sato, K. \& Katsura, T. (2001): Experimental investigation on dolomite dissociation into aragonite + magnesite up to $8.5 \mathrm{GPa}$. Earth Planet. Sci. Lett., 184, 529-534.

Scheetz, B.E. \& White, W.B. (1977): Vibrational spectra of the alkaline earth double carbonates. Am. Mineral., 62, 36-50.

Schertl, H.-P., Sobolev, N.V., Neuser, R.D., Shatsky, V.S. (2004): HP-metamorphic rocks from Dora Maira/Western Alps and Kokchetav/Kazakhstan: new insights using cathodoluminescence petrography. Eur. J. Mineral., 16, 49-57. 
Shatsky, V.S., Sobolev, N.V., Vavilov, M.A. (1995): Diamond-bearing metamorphic rocks of the Kokchetav massif (Northern Kazakhstan). Cambridge University Press, Cambridge, 427-455 pp.

Shatsky, V.S., Ragozin, A.L., Sobolev, N.V. (2006): Some aspects of metamorphic evolution of the ultrahigh-pressure calc-silicate rocks of the Kokchetav Massif. Russ. Geol. Geophys., 47, 105-118.

Smit, M.A., Bröcker, M., Scherer, E.E. (2008): Aragonite and magnesite in eclogites from the Jæren nappe, SW Norway: disequilibrium in the system $\mathrm{CaCO}_{3}-\mathrm{MgCO}_{3}$ and petrological implications. J. metamorphic Geol., 26, 959-979.

Smith, D.C. (1984): Coesite in clinopyroxene in the Caledonides and its implications for geodynamics. Nature, 310, 641-644.

Sobolev, N.V. \& Shatsky, V.S. (1990): Diamond inclusions in garnets from metamorphic rocks: a new environment for diamond formation. Nature, 343, 742-746.

Sokol, A.G., Borzdov, Y.M., Pal'yanov, Y.N., Khokhryakov, A.F., Sobolev, N.V. (2001): An experimental demonstration of diamond formation in the dolomite-carbon and dolomite-fluid-carbon systems. Eur. J. Mineral., 13, 893-900.

Thomsen, T.B. \& Schmidt, M.W. (2008): Melting of carbonated pelites at 2.5-5.0 GPa, silicate-carbonatite liquid immiscibility, and potassium-carbon metasomatism of the mantle. Earth Planet. Sci. Lett., 267, 17-31.

Van der Molen, I. \& van Roermund, H.L. (1986): The pressure path of solid inclusions in minerals: the retention of coesite inclusions during uplift. Lithos, 19, 317-324.

Vance, J.A. (1968): Metamorphic aragonite in the prehnite-pumpellyite facies, Northwest Washington. Am. J. Sci., 266, 299-315.

Williams, Q., Collerson, B., Knittle, E. (1992): Vibrational spectra of magnesite $\left(\mathrm{MgCO}_{3}\right)$ and calcite-III at high pressures. Am. Mineral., 77, 1158-1165.

Ye, K., Liou, J.B., Cong, B., Maruyama, S. (2001): Overpressures induced by coesite-quartz transition in zircon. Am. Mineral., 86, 1151-1155.

Zhu, Y.F. \& Ogasawara, Y. (2002): Carbon recycled into the deep Earth: evidenced by dolomite dissociation in subduction-zone rocks. Geology, 30, 947-950.

Received 11 January 2009

Modified version received 31 May 2009

Accepted 6 October 2009 